\title{
THE UTILIZATION OF VILLAGE-INFORMATION SYSTEM FOR INTEGRATED SOCIAL WELFARE DATA MANAGEMENT: ACTOR-NETWORK THEORY APPROACH IN GUNUNGKIDUL REGENCY
}

\author{
PENERAPAN SISTEM INFORMASI DESA UNTUK PENGELOLAAN \\ DATA TERPADU KESEJAHTERAAN SOSIAL: PENDEKATAN TEORI \\ JEJARING-AKTOR DI KABUPATEN GUNUNGKIDUL
}

\author{
Elanto Wijoyono* \\ Combine Resource Institution, Yogyakarta \\ Submitted:23-10-2020; Revised:15-09-2021; Accepted: 09-10-2021
}

\begin{abstract}
As the main reference to poverty alleviation in Indonesia, the policy of integrated welfare data management by the Ministry of Social Affairs still contains many inaccuracies. This has an impact on beneficiary groups as the target of the implementation of national programs on poverty reduction. This study shows how Integrated Social Welfare Data management by the local government in Gunungkidul Regency, Special Region of Yogyakarta, can solve the inaccuracy. The analysis was conducted with qualitative methods, based on actor-network theory. Data collection, verification, and validation are processed by integrating Village Information System (SID BERDAYA) and Regency Information System (SIKAB) in Gunungkidul at the local level, with the Social Welfare Information System - Next Generation (SIKS-NG) by the Ministry of Social Affairs in national level. This integration is needed to improve the quality of data accuracy and validity. Strengthening the participation and transparency of social interaction between government agencies at every level (from the village level to the national level) and the community people are important since communities are the beneficiaries. These processes will develop a reflective scheme, to make sure the quality of planning and development program on poverty alleviation is running with accurate and valid data.
\end{abstract}

Keywords: Information System; Poverty; Social Welfare; Village.

\begin{abstract}
ABSTRAK
Kebijakan pengelolaan data terpadu oleh Kementerian Sosial sebagai rujukan dalam program penanggulangan kemiskinan masih banyak mengandung ketidakakuratan, sehingga penargetan kelompok penerima manfaat masih sering tidak tepat sasaran. Kajian ini bertujuan untuk menganalisis praktik pengelolaan Data Terpadu Kesejahteraan Sosial yang diselenggarakan di Kabupaten Gunungkidul, Provinsi Daerah Istimewa Yogyakarta. Analisis dilakukan dengan metode kualitatif yang berlandaskan pada teori jejaring aktor. Proses pendataan, verifikasi, hingga validasi data kesejahteraan sosial dilakukan dengan mengintegrasikan Sistem Informasi Desa (SID BERDAYA) dan Sistem Informasi Kabupaten (SIKAB) yang ada di Kabupaten Gunungkidul dengan Sistem Informasi Kesejahteraan Sosial - Next Generation (SIKS-NG) di Kementerian Sosial untuk meningkatkan
\end{abstract}

* Corresponding author: joyo@combine.or.id Copyright @2021 THE AUTHOR(S). This article is distributed under a Creative Commons Attribution-Share Alike 4.0 International license. Jurnal Teknosains is published by the Graduate School of Universitas Gadjah Mada. 
kualitas akurasi dan validitas data. Berdasarkan proses yang dijalankan, perlu ada penguatan interaksi sosial yang partisipatif dan transparan antara pemerintah, pemerintah daerah, pemerintah desa, dan masyarakat yang menjadi sasaran pendataan. Dengan langkah tersebut akan didapatkan skema penanggulangan kemiskinan yang bersifat reflektif, sehingga kualitas perencanaan dan pembangunan yang dilakukan akan semakin tepat guna dengan data yang akurat.

Keywords: sistem informasi; kemiskinan; kesejahteraan sosial; desa.

\section{INTRODUCTION}

Gunungkidul is a part of regency in the Special Region of Yogyakarta (DIY) Province, Indonesia is divided into 18 districts and 144 villages. During 2016-2018, the status of the poverty rate in Gunungkidul was still in the second-lowest position in DIY Province. However, the BPS-Statistics Indonesia (BPS) DIY (2019) noted that the percentage of poor people in Gunungkidul tends to decline, from $19.34 \%$ (in 2016) and $18.65 \%$ (2017) to $17.12 \%$ (2018) of a total of 736,210 inhabitants (BPS Kabupaten Gunungkidul, 2019).

The social protection program has been optimized so that the average percentage of poor households benefiting from the program has increased. The recipients of the Program Beras Miskin ("Rice for the Poor" program) in 2016-2018 has reached $84.71 \%$. The number of poor people who receive Premium Assistance Beneficiaries (PBI) increased from $48.92 \%$ (2016) to $81.17 \%$ (2018). The problem is, data on households receiving social protection programs are still scattered in all decile. In fact, households in the large decile should not have the right to receive it (Dinas Kominfo Kabupaten Gunungkidul dan BPS Kabupaten Gunungkidul, 2019). The need to increase the accuracy of social welfare data is urgent.

The increasing accuracy process in updating the social welfare/poverty data with the Poverty Information System (Sistem Informasi Kemiskinan) is regulated in Gunungkidul District Regional Regulation Number 2 of 2015 concerning Poverty Reduction and its derivative regent regulations. The Gunung- kidul Regency Regional Poverty Reduction Coordination Team (TKPKD), through the Regional Body for Planning and Development of Gunungkidul Regency (BAPPEDA), positioned the Village Information System (Sistem Informasi Desa/SID) to carry out this function. The data processed comes from the results of 2015 Updating the Unified Database (PBDT). Activation of SID for 144 villages was carried out in 2015 which was prepared as a tool for updating the Unified Database (Basis Data Terpadu/BDT) or Integrated Social Welfare Data (DTKS) starting in 2016.

The Gunungkidul Regency Government has reviewed the potential use of SID to realize the concept of one regional data. The supports for integrated data management based on information technology will improve the accuracy and validity of data used in poverty reduction programs. The configuration of the empowered Village Information System (SID BERDAYA) and District Information System (SIKAB) platforms were implemented in Gunungkidul. The two systems are developed by Combine Resource Institution (CRI) since 2009 with Gunungkidul Regency as one of the pilot project implementation areas (Wijoyono, 2018).

As an effort to update the BDT, the Gunungkidul Regency Government is struggling for the integration of village and regional data with those in central/national. The process of building unified data runs from two directions. The central government's initiative through the implementation of the Social Welfare Information System - Next Generation (SIKS-NG) developed by the Social Welfare Data and Information Center (Pusat Data dan Informasi Kesejahteraan Sosial/PUSDATIN KESOS) by the Ministry of Social Affairs, combined with the Gunungkidul Government's initiative through the implementation of SID BERDAYA and SIK$\mathrm{AB}$ developed by CRI as a non-governmental organization.

How the integration process between SID BERDAYA and SIKAB with SIKS-NG can guarantee the production of an accurate 
and up-to-date DTKS quality, is a basic question. This paper is aimed to analyze the practice of implementing integration in the management of Gunungkidul Regency DTKS from village and district levels, to the national levels (within the scope of the Ministry of Social's authority). The research was conducted using a qualitative method through a case study approach, that is guided by the Actor-Network Theory (ANT) framework. Through the analysis carried out, it will be studied how the formal management procedures of DTKS are carried out, as well as tracing retrospectively the actors involved in the process.

Several studies on the implementation of the Village Information System (SID) have been conducted. However, no research addresses the issue of data management and its integration with SID support. One of the initial studies on SID was written by Dewi (2013), which analyzed the Actor-Network Theory based on the initiative of villages in pioneering e-government with SID. Later researches have focused more on issues of information management and public information disclosure at the village level through village websites (Along, 2016; Nilawati, 2019). Other research is more directed at testing, whether the implementation of SID in several regions in Indonesia is following the concept of "smart village" (by Universitas Gadjah Mada and The Ministry of Villages, Development of Disadvantaged Regions, and Transmigration), in welcoming the Industrial Revolution 4.0 era (Purwanto and Permadi, ed., 2019). Another research focus related to SID is on the issue of stakeholder collaboration in the application of e-government (Wahyuni, 2017) and integrated broadband village program management (Saputra, 2018).

The actor-network theory was born in the field of science and technology studies, spearheaded by three academics, namely Bruno Latour (1987, 1996, 2005), Michael Callon (1986), and John Law (1992). This theory was chosen since it can provide a comprehensive analysis. The focus is no longer agency in microscope or structure in macro, but rather on social processes with entities that rotate in the context of networks (Ritzer, 2011). The role of non-human entities and/or material objects or artifact sin a social context is contained (Latour, 2005).

The entities mentioned have a form and acquire their properties as a result of their relationship with other entities. It means that each entity in the network does not have any inherent qualities. Material objects are created and obtain their meaning in a network of relationships with other objects. Ritzer explains that in this theory the shift of focus from the agent brings the action to whatever is there, especially non-human networks and objects. Actors become part of the network. The actor is subordinated to the network and becomes obedient to the network. Actors belong to the network and they take on the properties of the entities they cover.

Actors in Network-Actor Theory are all elements that are connected in the system, and will naturally form a network. Actors who have the ability to control other actors are called actants, who can enter and exit a network based on their wants and interests. Actan is the main element and activator in the network (Latour, 1996). The network will bring together actors who have the same interests, and are not limited to human actors, but also non-human actors. The actor belongs to the network, is subordinated to the network. The term actan that borrowed from semiotics, is meant to imply that it is not only humans who act. Non-human entities can also perform actions, can become actants (Ritzer, 2011).

The process when an actor joins a network can be read as an act of translation, namely the movement from one status to another (Callon, 1986; Heeks, 2013). Through the concept of translation, it will be possible to explain why sometimes reality becomes stable or unstable in a certain period of time. There are four key moments in the translation formulated by Callon that can be used as an analytical tool in Actor-Network Theory, including (1) problematization, as the stage of problem formulation by key actors and defin- 
ing the roles of other actors; (2) interessement, as the stage of giving each actor a special role and identity so that they are interested in the activities offered; (3) enrolment, as the stage when there is a commitment of many actors to join the network, and (4) mobilization, as the stage when a large and strong alliance is formed. If the process takes place through a series of stable translations, the actor-network will get its shape and exist temporally and become durable. However, this situation can be uncovered again if there are disinteressement and new resistance, which makes stability de-stabilized (Yuliar, 2008).

The development of the Actor-Network Theory is related to the ideas of post-humanism and post-social, which reject the idea of the separation of humanity from the nonhuman world. Post-social ideas give rise to new forms of society with relationships that arise with the expansion of extraordinary objects in today's world, such as technology, consumer goods, and objects of knowledge (Ritzer, 2011). Thus, this theory will avoid the concept of technological determination which tends to lead to simplification of complexity by viewing technology as a uniform, undifferentiated unit. Technology as the driver of change, and that technology has the concept of autonomy that is "neutral" and "value-free" is no longer relevant (Priyatma, 2013).

This research uses qualitative with analytical descriptive methods. It focused on case studies of DTKS management through the integration of SIKS-NG with SID BERDAYA and SIKAB in Gunungkidul Regency in 2019. The chronology of BDT integration initiatives from the district to the national level started in 2017. However, the context of data integration as DTKS just occurred in 2019, following the development of regulations at the national level. In this study, the "complex" reality of the integration practice of the DTKS will be described. The data collection process was carried out by retrospectively tracing (flashback) of the actors that were relevant and related to the DTKS integration process.
Studying formal procedures in integrated management of DTKS from village to national level will be taken as the first step in meeting research objectives. Social actors involved in integrated data management will be traced retrospectively. The analysis process will begin by sorting and categorizing data from process notes, activity documentation, and discussion or coordination records. The data will be grouped into two broad categories, namely sociogram and technogram data. It refers to the physical or institutional characteristics of the data, as human or nonhuman (Latour, 1987). The next stage is to study the socio-technogram as a reference unit for direct interpretation. Analysis with the Actor-Network Theory framework will be carried out by referring to the socio-technogram, the representation stage, and the translation process (Nasution, 2018).

\section{RESULT AND DISCUSSION}

The concept of social welfare in Indonesia is formally stipulated in the Law of the Republic of Indonesia Number 11 of 2009, concerning Social Welfare. To realize social welfare, the local and national governments with the community are directed to be able to perform social service efforts. It is the responsibility to meet the basic needs of every citizen, which includes social rehabilitation, social security, social empowerment, and social protection. Poverty is one of the criteria for social problems in the context of implementing social welfare.

The concept of poverty alleviation is specifically regulated in Article 19 of the Social Welfare Law. It is the program policy and activities for the people, families, groups, and communities who have or do not have a source of livelihood and cannot fulfill proper needs. Poverty matters are then specifically regulated through Law Number 13 of 2011, concerning Handling of the Poor and Needy. This law mandates the holding of data on the poor whose results are determined and managed as integrated data, by the relevant ministries or institutions. 
Table 1.

The development of the unified database

\begin{tabular}{l|l}
\hline \multicolumn{1}{c|}{ Year } & \multicolumn{1}{c}{ The unified database programs } \\
\hline 2005 & National Socio-Economic Data Collection (PSE) by BPS \\
\hline 2008 & Data Collection for Social Protection Programs (PPLS) by BPS \\
\hline 2011 & Data Collection for Social Protection Programs (PPLS) by BPS \\
\hline 2015 & Updating the Unified Database (PBDT) by TNP2K \\
\hline 2016 & $\begin{array}{l}\text { Updating Integrated Data of the Poor Handling Programs (DT-PPFM) by Ministry of } \\
\text { Social Affairs }\end{array}$ \\
\hline 2017 & $\begin{array}{l}\text { Integrated Data Verification and Validation of the Handling of the Poor and Poor People } \\
\text { (DT PFM \& OTM) through SIKS-NG by Ministry of Social Affairs }\end{array}$ \\
\hline 2019 & Integrated Social Welfare Data (DTKS) by Ministry of Social Affairs \\
\hline
\end{tabular}

Source: Data analysis (2020)

The development of a unified database to support social protection and poverty reduction programs actually started in 2005. The National Team for the Acceleration of Poverty Reduction (TNP2K) noted that the evolution of efforts to clarify program targets or beneficiaries began with the 2005 National Socio-Economic Data Collection (PSE). PSE became the first poverty census in Indonesia, which contains data by name by address (BNBA) of poor households. This method is very different from previous data collection obtained through the National SocioEconomic Survey (SUSENAS) conducted by BPS-Statistics Indonesia. The data produced by SUSENAS is just the macro poverty data, which can only provide an aggregate estimate of the poor (TNP2K, 2017).

Data updating in the following stages is accompanied by various improvements, both in the method and management aspects of the data collection. Data updating is carried out by BPS-Statistics Indonesia every three years, through the 2008 Data Collection for Social Protection Programs (PPLS) and 2011 PPLS. Implementation of the 2010 Population Census (SP) has also increased the target coverage and accuracy of population and household data in data collection. The government then appointed TNP2K as the institution in charge of disseminating the results of data collection, with BPS as a field operator. The PPLS 2011 data was determined by TNP2K as the Unified DataBase (BDT).
In 2015, the national government established the PBDT program. TNP2K claims that there are three innovations in PBDT, including (1) an initial list of households compiled based on the results of the PPLS 2011, supplemented with data on membership updates for social protection programs, (2) accommodating a participatory approach with the active involvement of local governments and communities, through Public Consultation Forum (FKP) in agreeing on the target households for data collection, and (3) there is an improvement in the methodology for ranking household welfare status through the Proxy Mean Test (PMT) approach.

In 2016, BDT received a "new name" as the Integrated Data of the Poor Handling Programs (DT-PPFM), by the Regulation of the Minister of Social Affairs. This rule of Number 10 of 2016 is concerning the Mechanism of Using Integrated Data of the Poor Handling Programs (DT-PPFM). Furthermore, through the Circular Letter of the Minister of Social Affairs Number 1 of 2017 concerning Implementation of Integrated Data Verification and Validation, the obligation to update is mandated to district/city governments. The updating of DT-PPFM is carried out based on information technology, using SIKS-NG software. Social Services/ Offices from all regions have access to SIKSNG which was developed by the Ministry of Social Affairs' Pusdatinkesos. Through SIKS$\mathrm{NG}$, it is expected that regular verification 
and validation to improve data on program beneficiary targets can be carried out in an integrated manner.

Regulation by the Minister of Social Affairs Number 28 of 2017, is concerning General Guidelines for Integrated Data Verification and Validation of the Handling of the Poor and Poor People (DT PFM \& OTM). It stipulates that the task of processing and presenting data falls under the authority of the Ministry of Social Affairs. Activities undertaken include checking, cleaning, ranking, making lists, and tabulating data, as well as presenting data using SIKS-NG. To help carry out the verification and validation of DT PFM \& OTM through SIKS-NG, the Ministry of Social Affairs released the Integrated Service and Referral System (SLRT). This scheme is regulated through Regulation of the Minister of Social Affairs Number 15 of 2018, concerning SLRT for Handling the Poor People.

Through the Regulation of the Minister of Social Affairs Number 5 of 2019 concerning Integrated Social Welfare Data (DTKS), the data components that were previously scattered, are then compiled into one DTKS umbrella. It includes the Governmental Social Welfare Data, data on aid recipients and social empowerment, and data on potential and sources of social welfare. An important point in this regulation is the opening of options for the management of DTKS, which, although still managed centrally with SIKSNG, can also be managed by an information system that is integrated with SIKS-NG. Thus, the management of DTKS should be in line with Presidential Regulation Number 39 of 2019 concerning One Data Indonesia.

\section{Village Information System in Gunungkidul Regency}

The pilot implementation of SID in Gunungkidul was started in 2011. The SID BERDAYA application that was developed and facilitated by CRI, can be used as a data processing tool and public information processing (as a village website). Implementation is trained in stages with strict evaluation, ranging from local schemes (offline) to integrated/networked (online). In 2015, a year after Law No. 6/2014 on Villages was published, the Gunungkidul Regency Government established an integrated internet-based replication of the application of SID in 144 villages (Wijoyono, 2019).

Table 2 .

The development of Village Information System (SID) in Gunungkidul Regency

\begin{tabular}{l|l}
\hline \multicolumn{1}{c|}{ Year } & \multicolumn{1}{c}{ Development Phases } \\
\hline 2011 & The pilot implementation of SID was started \\
\hline 2015 & $\begin{array}{l}\text { Integrated internet-based replication of the application of SID BERDAYA in 144 } \\
\text { villages }\end{array}$ \\
\hline $2016 / 2017$ & $\begin{array}{l}\text { Synchronization of the BDT with population data from SIAK to SID BERDAYA, } \\
\text { updating the PBDT (cycle 1) }\end{array}$ \\
\hline $2017 / 2018$ & $\begin{array}{l}\text { Synchronization of the BDT/DTPFM with population data from SIAK to SID } \\
\text { BERDAYA, updating the BDT (cycle 2) - integration to SIKS-NG }\end{array}$ \\
\hline $2018 / 2019$ & $\begin{array}{l}\text { Synchronization of the DTKS with population data from SIAK to SID BERDAYA, } \\
\text { updating the DTKS (cycle 3) - integration to SIKS-NG }\end{array}$ \\
\hline
\end{tabular}

Source: Data analysis (2020)

In terms of technology, the principle of interconnection and interoperability means that there are no significant obstacles in building data integration. This means that there is no need for excessive application spending. Coordination of data management programs in the regions has become easier. The village government was promised not to be burdened with the task of inputting data in various applications, without being integrated. The application of SID emphasizes that realizing the unity of data cannot be achieved by ignoring the role and position of the village (Wijoyono, 2018). 


\section{Integration Process of Integrated Social Welfare Data}

The updating process was prepared by the TKPKD of Gunungkidul Regency, as soon as the BDT was received from TNP2K. Synchronization of the BDT with population data from the Population Administration Information System (SIAK) of Gunungkidul Population and Civil Registry Office in 2016, resulted from data per village is clean before being sent to each village. The verification and validation process is controlled by the village government, together with the Village TKPK. This participatory method was trained by BPS and BAPPEDA Gunungkidul at an early stage. The training was held in groups at the sub-district level, followed by the village government. The updated data is processed through one channel, namely SID Berdaya. This data is for 144 villages, which are located on the server of the Gunungkidul Kominfo Office which is aggregated with SIKAB. BDT is not permitted to be processed and sent via any medium other than SID Berdaya and SIKAB, as an integrated system controlled by the regency government. Updates are scheduled once per year concurrently. Gunungkidul has done three cycles of updating the BDT/DTKS until 2019.

By the end of Semester I of 2019, DTKS 144 villages updated from Semester II of 2018 were successfully sent to SIKS-NG. This pro- cess is the result of an intensive coordination series, between the Gunungkidul Regency Government and the Social Service Center for the Ministry of Social Affairs. The purpose of this process is not only so that the village government does not input the same data in various applications, but also to ensure that there is duplicate data in the governance of the DTKS at the village, district, and national levels. It is hoped that the data on the target recipients of the social assistance program --both with funding sources from the Village APBD, Regency APBD, Provincial $\mathrm{APBD}$, and APBN-- can be legally taken from the same data sourced from the village. Village sovereignty over data is also maintained (BAPPEDA Gunungkidul Regency, 2019).

The integration of DTKS from SID Berdaya and SIKAB to SIKS-NG brings together the roles of actors from every level where the information technology innovation is done by all parties. Towards One Data Indonesia, the development of information technology with the principle of interoperability and policy direction (Nugroho, 2018) should make the integration between systems is easier. However, the situation has its complexities, so the principles that have been designed, may not necessarily produce the expected results. At this point, the analysis with the Actor-Network Theory is carried out through the lens of translational moments.

\section{Integration of DTKS in Actor-Network Theory Analysis}

Table 3.

The socio-technogram analysis

\begin{tabular}{l|l}
\hline Socio-technogram & \multicolumn{1}{c}{ Actors } \\
\hline $\begin{array}{l}\text { Sociogram } \\
\text { (the human }\end{array}$ & - Central agencies, such as the Ministry of Social Affairs, PUSDATIN KESOS, \\
actors) & The Ministry of National Development Planning or National Development \\
& Planning Agency (BAPPENAS), TNP2K, BPS-Statistics Indonesia \\
& - Regional agencies in Gunungkidul Regency: BAPPEDA, Social Service/ \\
& Office, BPS, TKPKD, sub-districts, and villages \\
& - NGO: Combine Resource Institution \\
\hline $\begin{array}{l}\text { Tehonogram } \\
\text { (the non-human } \\
\text { actors) }\end{array}$ & $\begin{array}{l}\text { Data processing instrument (application/software): SID BERDAYA, SIKAB, } \\
\text { SIKS-NG, SIKS-droid }\end{array}$ \\
& $\begin{array}{l}\text { Internet networks and information technology tools: village computers and } \\
\text { the Kominfo Office server }\end{array}$ \\
& Various reference documents, such as statutory regulations, data collection \\
& forms, and data collection guidelines. \\
\hline
\end{tabular}

Source: Data analysis (2020) 
This section will describe integration initiatives using the perspective of the sociology of translation. It is necessary to map who and/or what actor-networks in this context, at the very first stage. The human actors (as sociogram) in this initiative consist of central agencies, such as the Ministry of Social Affairs' PUSDATIN KESOS, BAPPENAS, TNP2K, and BPS-Statistics Indonesia; regional agencies in Gunungkidul Regency, such as BAPPEDA, Social Service/Office, BPS, TKPKD, sub-districts, and villages; and CRI. Non-human actors (as technogram) in this initiative consist of the application of SID BERDAYA, SIKAB, and SIKS-NG as data processing instruments; internet networks and information technology tools, such as village computers and the Kominfo Office server; as well as various reference documents, such as statutory regulations, data collection forms, and data collection guidelines.

The entire entity is analyzed for its role in each of the following:

1. Problematization. The paradigm of developing SID was developed by CRI, based on the process of meeting the village needs, not based on the desire to create applications. The process that is running in Gunungkidul can be supported by participatory data management factors from the village level. Another factor is the collaboration and distribution of authority between regional apparatus organizations (OPD) at the district level, which is well coordinated. These factors may not be found and manifested smoothly in every region. Inappropriate leadership can render the SID initiative useless. On the other hand, there are still big questions about how integration takes place at the ministry or agency at the national level. Experience shows that the coordination process to promote integration is not easy enough at the district level. The process in several regions proved to be a failure because it was done too sectorally or partially by the relevant OPDs.

2. Interessement. The data generated through the application of SID BERDAYA and SIKAB in Gunungkidul Regency have been tried to be integrated with the information system of three ministries, including the Ministry of Social Affairs (SIKS-NG), the Ministry of Health (Healthy Family Application), and the Ministry of Home Affairs (Regional Government Information System / SIPD). The technical integration process has been successfully done. Through SID BERDAYA and SIKAB, Gunungkidul Government can prove, that the local government is ready to manage integrated data management tasks which are mandated separately to ministries/agencies.

The data in SID BERDAYA and SIKAB have been used for development planning in Gunungkidul, although there are still many social protection programs with APBN funds with much different unintegrated data. Gunungkidul Government continues to urge the national government to recognize regional data by ministries/ agencies, to make sure the principle of One Data Indonesia can be realized immediately. There must be solid and harmonious referral regulations, supported by the consistency between the policies set by the president and the ministries/agencies. Gunungkidul Government even hopes, that there will be a poverty reduction program model in Gunungkidul which is directly conducted by the ministries or national agencies. It is because there is already integrated data available, started from the village level in SID BERDAYA and SIKAB.

3. Enrolment. During a national-level focus group discussion on Sept 24, 2019, conducted by CRI, The Ministry of Home Affairs admits that each party is still running independently, even though there is a direction towards the concept of One Indonesian Data. Poverty alleviation programs are still divided into the context of central, regional, and village authorities. The chaotic data management exists at the ministry/agency level since the crosssector integration has not yet occurred. BAPPENAS reminded that PBDT, which was instructed by the President to be done 
by BPS in 2015, will be combined with data collection which is the role of the Ministry of Social Affairs, TNP2K, and BKKBN. In 2019, DTKS has been managed with SIKSNG by the Ministry of Social Affairs and the verification and validation process should have been much better.

This revolution in the development of data management has helped improve the accuracy of targeting poverty reduction programs. There is a potential budget of up to 200 trillion rupiahs which can be used in poverty alleviation programs, starting from the state budget, regional budget, CSR, to zakat donation. However, if the data is still confusing, no matter how much the budget, it will not be effective. BAPPENAS assessed that cleaning data from below would make data more accurate. The potential of this initiative must be exploited. Each party can support each other so that activities that can be done at the village level no longer need to be budgeted at the ministry/agency level.

The Ministry of Social Affairs claims that data and information systems for poverty reductionareintegrated.Several ministries/ agencies and local governments have integrated the system with the Ministry of Social Affairs, including Gunungkidul. The mechanism for updating data must be from the Minister of Social Affairs according to the authority. Data and information management can still be carried out by the respective ministries/agencies or local governments. The Ministry of Social Affairs still believes that a centralized information system, such as SIKS-NG, will be more helpful to the regions. Villages and regions do not need to build their own applications. The budget funds they have can be used for other matters. The poverty data collection mechanism has been integrated with SIKSNG so that villages and regions do not need to be confused. The security system has also been prepared, that the data belongs to the villages and regions. The Ministry of Social Affairs has a regulatory role. It was promised that the data from the updating would be returned to the regions and villages. However, in reality, the DTKS returned by the central government to the regions is not always the same as the updated results.

4. Mobilization. By the end of 2019, BAPPENAS came to Gunungkidul to see the implementation of SID Berdaya and SIKAB. They continue to support the DTKS integration initiative through SID Berdaya and SIKAB. Several challenges are arising from the technical process. The integration process of DTKS as a result of the updating of Semester I of 2019 did not run smoothly, because SIKS-NG was designed not to be directly connected to SID BERDAYA and SIKAB, but through data interoperability. PUSDATIN KESOS of the Ministry of Social Affairs prepared a special application for Gunungkidul, in the form of an offline version of SIKS-NG. It is used to bridge the process of integrating DTKS from SIKAB to SIKS-NG, which makes the running process becomes longer.

A new problem arose. Updating the DTKS with the SIKS-droid application based on the direction of the Ministry of Social Affairs will begin in Semester II of 2019. It is uncertain whether the verification and validation process for the next period of DTKS can still use SID BERDAYA and SIKAB or not. The integration of the DTKS from SID BERDAYA and SIKAB to SIKS-NG had to be postponed to avoid overlapping data collection processes and results. However, updating many DTKS indicators in SID BERDAYA and SIKAB specifically aimed at poverty reduction program needs with district APBD funding sources are still being carried out. Thus, there was a de-enrolment process that emerged from the Ministry of Social Affairs, which then disrupted the mobilization process that should have been obtained.

Various concepts and integration schemes have been formulated by the government towards the One Data Indonesia vision, including in the context of poverty reduction. However, it turns out that these 
plans can be affected and change rapidly when certain technological developments come. When the principle of data interoperability has been agreed upon, the Ministry of Social Affairs should be consistent in opening access to the integration of the DTKS to
SIKS-NG from regions or ministries/institutions that are ready to do so. However, the Ministry of Social Affairs seems to prioritize the continuity of the process of updating the DTKS which is controlled and centralized with devices that are considered easier, namely the SIKS-droid.

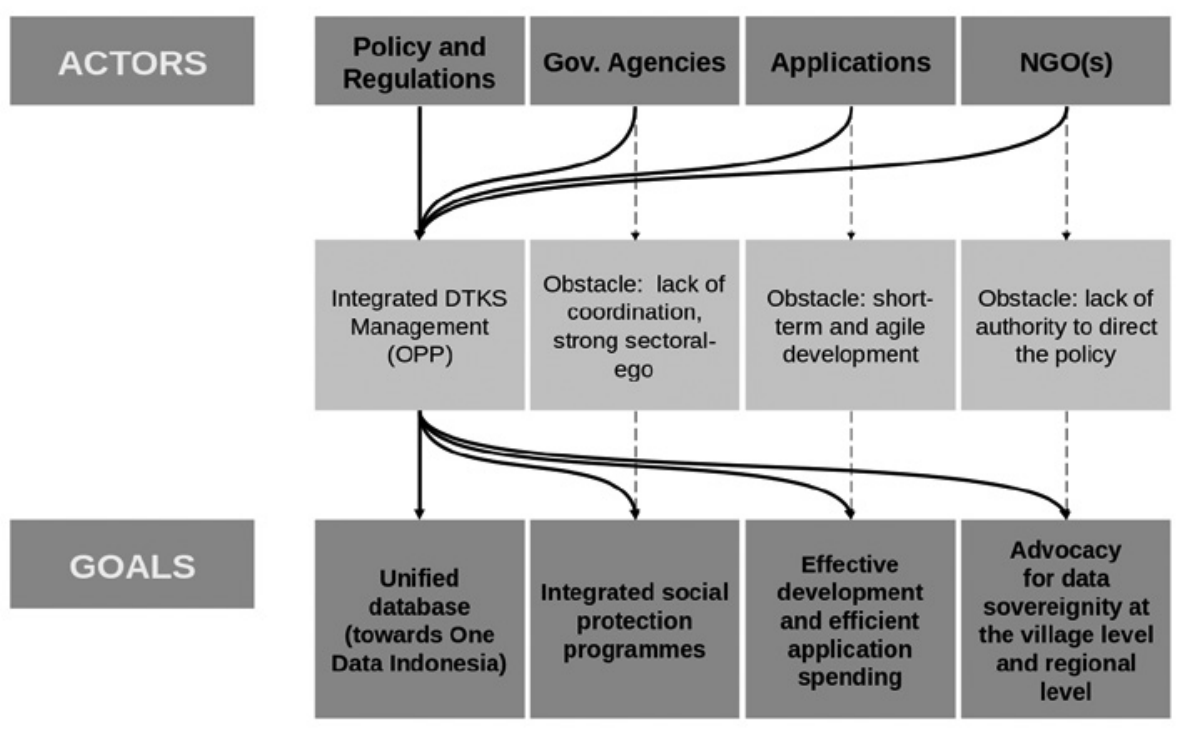

Figure 1.

Process and results of the translation Source: author (adapted from Callon (1986))

On the one hand, the choice of technology is considered to facilitate the process of updating the DTKS in the field, but on the other hand, it complicates the integration scheme with various other systems that have been previously designed. The potential for overlapping processes and results of DTKS data collection will continue to occur when the Ministry of Social Affairs is still ambiguous, promising to be open to the integration process so that the process is more effective and efficient, but still requires the use of the technological tools they develop at the same time.

For the center, this process will be more effective, but for villages and regions, it has the potential to reduce their sovereignty over the data. Villages and regions cannot store and process DTKS independently with SID BERDAYA and SIKAB. The update of DTKS is also prone to appear in different versions so that it is back away from the vision of one data that was outlined by all parties. Efforts should be made to strengthen shared understanding and commitment on the agenda for data integration at the village, regional and national levels so that the achievements of poverty alleviation programs can be realized through integrated data that is accurate and valid.

\section{CONCLUSION}

The integration process of DTKS through SID BERDAYA and SIKAB to SIKSNG proves that there are social and technical processes, there are negotiation and re-negotiation processes, which run simultaneously and take place continuously. Agreements emerged from the choice of stages, methods, to the work tools used. The integration process of the DTKS is then the result is strongly influenced by the commitment and accuracy 
factor in the application of the data collection methodology carried out by the collaborative work team from the district to village level, as well as in the data processing procedure with SID BERDAYA and SIKAB, before then the database in it is sent to SIKS- NG. This means that there are human actors and nonhuman actors involved.

From the four moments of translation, it can be concluded that it is important to have more intensive interaction and communication that is dialogic in nature so that the involvement and understanding of the actors in each stage of the DTKS integration process can be increased. This interaction is expected to encourage the updating and use of reflective DTKS, as a learning medium for parties in understanding the process of realizing development data in the social welfare sector or poverty management.

\section{BIBLIOGRAPHY}

Along, Antonius. 2016. Pemanfaatan Sistem Informasi Desa (SID) untuk Keterbukaan Informasi Publik (KIP); Studi Deskriptif Kualitatif tentang Pemanfaatan Sistem Informasi Publik untuk Keterbukaan Informasi Publik di Desa Dlingo, Kecamatan Dlingo, Kabupaten Bantul, Provinsi Daerah Istimewa Yogyakarta. Script. Sekolah Tinggi Pembangunan Masyarakat Desa APMD Yogyakarta. Yogyakarta.

Badan Pusat Statistik Kabupaten Gunungkidul. 2019. Statistik Daerah Kabupaten Gunungkidul 2019. Badan Pusat Statistik Kabupaten Gunungkidul. Wonosari.

Badan Pusat Statistik Provinsi Daerah Istimewa Yogyakarta. 2019. Data Strategis Daerah Istimewa Yogyakarta 2019. Badan Pusat Statistik Provinsi Daerah Istimewa Yogyakarta. Yogyakarta. Yogyakarta.

Bappeda Kabupaten Gunungkidul. 2019. "Pemerintah Kabupaten Gunungkidul Terus Kembangkan SIDA
SAMEKTA". BAPPEDA Kabupaten Gunungkidul. http://bappeda. gunungkidulkab.go.id/pemkabgunungkidul-terus-kembangkansida-samekta/. Accessed 6 March 2020.

Callon, Michel. 1986. "Some elements of a sociology of translation; domestication of the scallops and the fishermen of St Brieuc Bay". In Power, Action, and Belief; A New Sociology of Knowledge?. Sociological Review Monograph 32. Editor John Law. Routledge \& Kegan Paul. London

Dewi, Ambar Sari. 2013. Membuat e-Government Bekerja di Desa; Analisis Actor-Network Theory terhadap Sistem Informasi Desa dan Gerakan Desa Membangun. Jurnal Mandatory, 10(2): 89-114.

Dinas Komunikasi dan Informatika Kabupaten Gunungkidul dan Badan Pusat Statistik Kabupaten Gunungkidul. (2019). Analisis Kemiskinan Kabupaten Gunungkidul 2019. Dinas Komunikasi dan Informatika Kabupaten Gunungkidul dan Badan Pusat Statistik Kabupaten Gunungkidul. Wonosari.

Heeks, Richard. 2013. Development Studies Research and Actor-Network Theory. Actor-Network Theory for Development; Working Paper Series, Paper No. 1. Centre for Development Informatics Institute for Development Policy and Management University of Manchester. Manchester.

Latour, Bruno. 1987. Science in Action; How to Follow Scientists and Engineers Through Society. Milton Keynes: Open University Press.

Latour, Bruno. 1996. On Actor-Network Theory; A few clarifications plus more than a few complications. Soziale Welt, 47. Jahrg., H.4: 369-381.

Latour, Bruno. 2005. Reassembling the Social; An Introduction to Actor-Network- 
Theory. Oxford University Press. New York.

Law, John. 1992. Notes on the theory of the actor-network: Ordering, strategy, and heterogeneity. Systems Practice 5(4): 379-393.

Nasution, Ahmadriswan. 2018. Penyelenggaraan Pengukuran Tingkat Kemiskinan di Badan Pusat Statistik; Pendekatan Teori Jejaring-Aktor. Jurnal Sosioteknologi, 17(1): 154 - 169.

Nilawati, Evi. 2019. Kecenderungan Isi Sistem Informasi Desa di Kabupaten Gunungkidul. IPTEK-KOM, 21(2): 169-184.

Nugroho, Yanuar. 2018. Satu Nusa, Satu Bangsa, Satu Data. Harian KOMPAS. 16 Oktober. Page 7. Jakarta

Peraturan Menteri Sosial Republik Indonesia Nomor 10 Tahun 2016 tentang Mekanisme Penggunaan Data Terpadu Program Penanganan Fakir Miskin. 3 Mei 2016. Berita Negara Republik Indonesia Tahun 2016 Nomor 705. Jakarta.

Peraturan Menteri Sosial Republik Indonesia Nomor 28 Tahun 2017 tentang Pedoman Umum Verifikasi dan Validasi Data Terpadu Penanganan Fakir Miskin dan Orang Tidak Mampu. 29 Desember 2017. Berita Negara Republik Indonesia Tahun 2018 Nomor 184. Jakarta.

Peraturan Menteri Sosial Republik Indonesia Nomor 15 Tahun 2018 tentang Sistem Layanan dan Rujukan Terpadu untuk Penanganan Fakir Miskin dan Orang Tidak Mampu. 2 Agustus 2018. Berita Negara Republik Indonesia Tahun 2018 Nomor 1062. Jakarta.

Peraturan Menteri Sosial Republik Indonesia Nomor 5 Tahun 2019 tentang Pengelolaan Data Terpadu Kesejahteraan Sosial. 22 Juni 2019. Berita Negara Republik Indonesia Tahun 2019 Nomor 732. Jakarta.
Peraturan Presiden Republik Indonesia Nomor 39 Tahun 2019 tentang Satu Data Indonesia. 12 Juni 2019. Lembaran Negara Republik Indonesia Tahun 2019 Nomor 112. Jakarta.

Priyatma, Johanes Eka. 2013. “Potensi Teori Jejaring Aktor untuk Memahami Inovasi Teknologi". in Seminar Riset dan Teknologi Terapan (RiTekTra) 2013 Jakarta 26-27 September.

Purwanto, Erwan Agus dan Dedy Permadi, ed.. 2019. Desa Cerdas; Transformasi Kebijakan dan Pembangunan Desa Merespon Era Revolusi Industri 4.0. Center for Digital Society (CfDS) dan Institute of Governance and Public Affairs (IGPA) Universitas Gadjah Mada. Yogyakarta.

Ritzer, George. 2011. Eighth Edition Sociological Theory. Terjemahan Saut Pasaribu, Rh. Widodo, and Eka Adi Nugraha. 2012. Teori Sosiologi; Dari Sosiologi Klasik Sampai Perkembangan Terakhir Posmodern. Cetakan 1. Pustaka Pelajar. Yogyakarta.

Saputra, Febri Setiawan Eka. 2018. Analisis Keterlibatan Stakeholder dalam Program Desa Broadband Terpadu di Desa Karangmojo, Kecamatan Karangmojo dan Desa Putat, Kecamatan Patuk, Kabupaten Gunungkidul, Daerah Istimewa Yogyakarta. Script. Universitas Islam Indonesia. Yogyakarta.

Tim Nasional Percepatan Penanggulangan Kemiskinan. 2017. Basis Data Terpadu 2015; untuk Memilah Penerima Manfaat Program Penanganan Fakir Miskin Berdasarkan Parameter yang Diinginkan. Tim Nasional Percepatan Penanggulangan Kemiskinan (TNP2K) Sekretariat Wakil Presiden Republik Indonesia. Jakarta.

Undang-Undang Republik Indonesia Nomor 11 Tahun 2009 tentang Kesejahteraan Sosial. 16 Januari 2009. Lembaran 
Negara Republik Indonesia Tahun 2009 Nomor 12. Jakarta.

Undang-Undang Republik Indonesia Nomor 13 Tahun 2011 tentang Penanganan Fakir Miskin. 18 Agustus 2011. Lembaran Negara Republik Indonesia Tahun 2011 Nomor 83. Jakarta.

Undang-Undang Republik Indonesia Nomor 6 Tahun 2014 tentang Desa. 15 September 2014. Lembaran Negara Republik Indonesia Tahun 2014 Nomor 7. Jakarta.

Wahyuni, Sri. 2017. Collaboration Governance antara Pemerintah Kabupaten Bantul dengan Swasta dalam Pengelolaan e-Government; Studi Kasus Desa Jatimulyo, Kecamatan Dlingo dengan Combine Resource Institution tahun 2016". Script. Universitas Muhammadiyah Yogyakarta. Yogyakarta.
Wijoyono, Elanto. 2018. Sistem Informasi Desa setelah UU Desa. https:// www.krjogja.com/angkringan/ opini/sistem-informasi-desasetelah-uu-desa/. Accessed 6 March 2020 (15.00)

Wijoyono, Elanto. 2018. Satu Data dengan Sistem Informasi Desa. Combine Resource Institution. Majalah Kombinasi Edisi 72. Page 8 - 17. Yogyakarta.

Wijoyono, Elanto. 2019. Menuju Satu Data Indonesia melalui Interoperabilitas Data Sistem Informasi Desa (SID) Berdaya dan Sistem Informasi Kabupaten (SIKAB); Konsep dan Implementasinya di Kabupaten Gunungkidul. https://www. combine.or.id/archive/74. 8 March 2020 (10.00).

Yuliar, Sonny. 2008. Tata Kelola Teknologi dalam Perencanaan Sektor Publik. Jurnal Perencanaan Wilayah dan Kota, 19(3): $21-38$. 